\title{
OCHRONA HUMANITARNA ZWIERZĄT UTRZYMYWANYCH W OGRODACH ZOOLOGICZNYCH
}

\section{Wstęp}

Tematyka ochrony zwierząt stanowi zagadnienie interdyscyplinarne, będące niezmiennie przedmiotem zainteresowań badawczych zarówno przedstawicieli nauk przyrodniczych, jak i społecznych - w tym również prawa. Szczególną kategorię ochrony zwierząt stanowi ochrona humanitarna. Stanowi ona, obok ochrony gatunkowej, użytkowej i weterynaryjnej ${ }^{1}$, podstawowy przejaw zagwarantowania zwierzętom odpowiednich warunków i zapewnienia im wolności od bólu lub cierpienia. Obejmuje ona szerokie spektrum zagadnień, wchodzących w jej zakres, dostosowujących odpowiednie rozwiązania prawne do różnych kategorii zwierząt. Wśród nich wymienić można m.in. zwierzęta utrzymywane w ogrodach zoologicznych.

Utrzymywanie zwierząt $w$ ogrodach zoologicznych uznawane jest często za kwestię kontrowersyjną. Jej przeciwnicy uznają, że stanowi ono przejaw pozbawienia zwierząt wolności i ograniczania ich naturalnych potrzeb. Ponadto niejednokrotnie warunki panujące w ogrodach zoologicznych oraz sposób oddziaływania na umieszczone w nich zwierzęta - zarówno ze strony personelu, jak i odwiedzających, mogą wywoływać u nich negatywne odczucia w postaci bólu lub cierpienia. Może to zatem prowadzić do wniosku, że umieszczanie zwierząt w ogrodach

\footnotetext{
* Dr, Katolicki Uniwersytet Lubelski Jana Pawła II; e-mail: zuzanna.gadzik@kul.pl, ORCID ID: https:/ / orcid.org/0000-0002-9121-4658.

1 Szerzej na temat podziału prawnej ochrony zwierząt zob. Ł. Smaga, Ochrona humanitarna zwierzat, Białystok 2010, s. 97 i nast.
} 
zoologicznych stanowi przejaw ich niehumanitarnego traktowania. Z drugiej strony, podnosi się, że umieszczanie i hodowla zwierząt w ogrodach zoologicznych często stanowi jedyną szansę na przeżycie - zarówno dla poszczególnych osobników, jak i całych zagrożonych wyginięciem gatunków. Biorąc pod uwagę powyższe, konieczne stało się wprowadzenie do porządku prawnego odpowiednich przepisów, które w sposób kompleksowy uregulowałyby kwestie utrzymywania zwierząt $\mathrm{w}$ ogrodach zoologicznych i zapewnienia im w nich odpowiednich warunków. Zasadne staje się wobec tego zbadanie, w jakim zakresie przepisy te wpisują się w zakres przesłanek ochrony humanitarnej zwierząt i za pomocą jakich środków ochrona tego typu jest im zagwarantowana.

\section{Ochrona humanitarna zwierząt}

Za podstawowe normy, urzeczywistniające ochronę humanitarną zwierząt ${ }^{2}$, uznać należy przepisy art. 1 ust. 1 oraz art. 5 ustawy z dnia 21 sierpnia 1997 r. o ochronie zwierząt ${ }^{3}$. Zgodnie z pierwszym uregulowaniem zwierzę, jako istota żyjąca, zdolna do odczuwania cierpienia, nie jest rzeczą. Człowiek jest mu winien poszanowanie, ochronę i opiekę. Z drugiego wynika natomiast, iż każde zwierzę wymaga humanitarnego traktowania. W związku z tym przyjmuje się, że ochrona humanitarna zwierząt stanowi przejaw ochrony zwierząt przed działaniami człowieka, które sprowadzają się do zadawania im cierpienia. Opiera się na pobudkach etycznych, wynikających z założenia, że zwierzę, jako istota zdolna do odczuwania bólu i cierpienia, zasługuje na ochronę przed okrutnym traktowaniem, godzącym w jego życie i zdrowie ${ }^{4}$. W jej kontekście podkreśla się

2 Słusznym rozwiązaniem - jak podnosi J. Woleński - byłoby stosowanie pojęcia „animalitaryzm” zamiast „humanitarnym”. Pierwsze z nich stanowi bowiem termin bardziej pojemny, zob. tenże, Podmiotowość zwierząt w aspekcie filozoficzny, [w:] T. Gardocka, A. Gruszczyńska (red.), Status zwierzęcia. Zagadnienia filozoficzne i prawne, Torun 2012, s. 26 i nast.

3 Ustawa z dnia 21 sierpnia 1997 r. o ochronie zwierząt, tekst jednolity: Dz. U. z 2020 r. poz. 638 (dalej: u.o.z.).

4 Zob. L. Jastrzębski, Prawo ochrony środowiska w Polsce, Warszawa 1990, s. 124; W. Radecki, Ustawa o ochronie zwierząt. Komentarz, Warszawa 2012, s. 14 i nast.; Ł. Smaga, Ochrona humanitarna..., s. 109. 
przede wszystkim potrzebę uświadomienia i usankcjonowania zdolności zwierząt do odczuwania przez nie negatywnych wrażeń zmysłowych i emocjonalnych. Zdolności tej nie można przyznać bowiem wyłącznie człowiekowi, lecz w ogóle wszystkim istotom żyjącym ${ }^{5}$. W tym miejscu zaznaczyć należy, iż z powyższego stwierdzenia nie wynika personalizacja zwierząt, a jedynie ustalenie pewnego właściwego sposobu ich traktowania ${ }^{6}$. Ochrona humanitarna stanowi również pewnego rodzaju ograniczenie przysługujących człowiekowi praw i wolności. W sytuacjach, gdy ludzkie działanie mogłoby wiązać się z nieuzasadnionym i okrutnym naruszaniem dobra zwierząt, może mieć bowiem miejsce zawężenie ich zastosowania ${ }^{7}$. Ochrona humanitarna zwierząt powstrzymuje dowolność zachowań człowieka, ustalając jednocześnie granicę praw i obowiązków wobec zwierząt, których naruszenie może wiązać się z określonymi sankcjami prawnymi ${ }^{8}$.

Przyjmuje się, że podstawą ochrony humanitarnej zwierząt jest przyznanie im zdolności do odczuwania negatywnych bodźców - zwłaszcza bólu i cierpienia. Dotyczy to nie tylko negatywnych odczuć o charakterze fizycznym (związanym np. ze zranieniem zwierzęcia), ale również psychicznym (jak np. wywołanie poczucia strachu lub porzucenie zwierzęcia). Istniejące uregulowania prawne odnoszące się do ochrony humanitarnej zwierząt, nakierowane są zatem przede wszystkim na wyeliminowanie możliwości zadawania ich zwierzętom, a przynajmniej na znaczne ich ograniczenie. Zgodnie z przepisem art. 4 pkt 2 u.o.z. przez humanitarne traktowanie zwierząt rozumie się traktowanie uwzględniające potrzeby zwierzęcia i zapewniające mu opiekę i ochronę. Wobec tego niehumanitarnym traktowaniem będą wszelkiego rodzaju zachowania, które będą wymierzone w powyższe wartości.

Warto również zaznaczyć, iż ochrona humanitarna zwierząt ma charakter dwutorowy. Dzieli się na ochronę humanitarną ogólną (generalną) oraz

5 Zob. M. Gabriel-Węglowski, Przestępstwa przeciwko humanitarnej ochronie zwierząt, Toruń 2008, s. 32.

6 Zob. Ł. Smaga, Ochrona humanitarna..., s. 110; odmiennie L. Jastrzębski, Prawo ochrony środowiska..., s. 124.

7 Zob. A. Majewski, Prawa człowieka a prawa zwierząt, "Gdańskie Studia Prawnicze” 2005, t. 13, s. 58; tenże, Aksjologiczne podstawy prawnej ochrony zwierzat w aspekcie humanitarnym, „Gdańskie Studia Prawnicze” 2000, t. 7, s. 365 i nast.

8 Szerzej zob. Z. Gądzik, Prawnokarna ochrona zwierząt wykorzystywanych w procedurach doświadczalnych, Lublin 2018, s. 119 i nast. 
ochronę humanitarną szczególną (specjalną). Pierwsza z nich jest dedykowana wszystkim zwierzętom ${ }^{9}$ i obejmuje normy prawne, które mają na celu zagwarantować ich ochronę - niezależnie od gatunku oraz celu, dla którego wykorzystane ma być zwierzę. Przepisy te zawarte zostały we wskazanej ustawie o ochronie zwierząt. Ochrona humanitarna szczególna stanowi lex specialis w stosunku do ochrony generalnej. Dotyczy ona zwierząt, które z uwagi na szczególne właściwości lub cel ich wykorzystywania, wymagają odmiennych, odpowiednio zmodyfikowanych warunków swojej ochrony, np. ochrona zwierząt wykorzystywanych w procedurach doświadczalnych (uregulowana na gruncie przepisów ustawy z dnia 15 stycznia 2015 r. o ochronie zwierząt wykorzystywanych do celów naukowych lub edukacyjnych ${ }^{10}$ ) lub ochrona zwierząt łownych (wynikająca z przepisów ustawy z dnia 13 października 1995 r. - Prawo łowieckie ${ }^{11}$ ). Powyższe przepisy znajdują pierwszeństwo przed normami o charakterze ogólnym (wynikającymi z ustawy o ochronie zwierząt). Jedynie w przypadku, gdy określone kwestie nie zostały uregulowane $\mathrm{w}$ ramach ustaw szczegółowych, konieczne staje się odniesienie do przepisów ogólnych.

Pomimo że zwierzęta utrzymywane w ogrodach zoologicznych stanowią szczególną kategorię zwierząt, nie wyróżnia się odrębnego aktu prawnego, na podstawie którego możliwa byłaby ich specjalistyczna ochrona. W związku z tym przyjąć należy, że podlegają one ochronie na gruncie przepisów u.o.z.

\section{Zwierzęta utrzymywane w ogrodach zoologicznych}

Zwierzęta utrzymywane w ogrodach zoologicznych stanowią szczególną kategorię zwierząt, która wymaga specjalnego traktowania i odpo-

9 Dotyczy to jednak wyłącznie zwierząt kręgowych, gdyż zgodnie z przepisem art. 2 ust. 1 u.o.z. ustawa reguluje postępowanie ze zwierzętami kręgowymi. Oznacza to, że poza zakresem ochrony humanitarnej zwierząt pozostają osobniki z podtypu bezkręowców (np. owady, mięczaki, stawonogi). Przyjmuje się, że wiąże się to ze specyficzną budową układu nerwowego kręgowców, który umożliwia przewodzenie bodźców bólowych.

10 Ustawa z dnia 15 stycznia 2015 r. o ochronie zwierząt wykorzystywanych do celów naukowych lub edukacyjnych, tekst jednolity: Dz. U. z 2019 r. poz. 1392.

11 Ustawa z dnia 13 października 1995 r. - Prawo łowieckie, tekst jednolity: Dz. U. z 2020 r. poz. 67. 
wiedniej ochrony. W wielu przypadkach są to przedstawiciele gatunków zagrożonych wyginięciem, których umieszczenie w ogrodach zoologicznych stanowi jedyną szansę na ich przetrwanie. Prócz tego często są to zwierzęta, które nie występują naturalnie w kraju, w którym umiejscowiony jest ogród zoologiczny, co wiąże się z koniecznością stworzenia im odpowiednio dostosowanych warunków bytowych.

Uregulowania prawne dotyczące zwierząt utrzymywanych w ogrodach zoologicznych pierwotnie umiejscowione zostały w ustawie o ochronie zwierząt (art. 19 i nast. u.o.z.). Przepisy te zostały uchylone na gruncie ustawy z dnia 16 kwietnia 2004 r. o ochronie przyrody ${ }^{12}$, w której to, w rozdziale III (Ogrody botaniczne, ogrody zoologiczne oraz ośrodki rehabilitacji zwierząt) wprowadzone zostały analogiczne, odpowiednio poszerzone przepisy odnoszące się do tej problematyki. Szczegółowe unormowania dotyczące warunków hodowli i utrzymywania poszczególnych grup zwierząt w ogrodach zoologicznych, zawarte zostały dodatkowo w rozporządzeniu Ministra Środowiska z dnia 20 grudnia 2004 r. w sprawie warunków hodowli i utrzymywania poszczególnych grup gatunków zwierząt w ogrodzie zoologicznym ${ }^{13}$.

Uwzględniając definicję ogrodu zoologicznego, określoną w przepisie art. 5 pkt 11 u.o.p., zwierzęciem utrzymywanym w ogrodzie zoologicznym będzie zwierzę gatunku dziko występującego ${ }^{14}$, stale przebywające na terenie odpowiednio urządzonym i zagospodarowanym wraz z infrastrukturą techniczną i budynkami funkcjonalnie z nimi związanymi, gdzie są przetrzymywane oraz eksponowane publicznie przez przynajmniej siedem dni w roku zwierzęta gatunków dziko występujących. Ustawodawca poczynił jednocześnie zastrzeżenie, iż ogrodem zoologicznym nie będą cyrki, sklepy ze zwierzętami oraz miejsca, w których eksponowanych jest publicznie nie

12 Ustawa z dnia 16 kwietnia 2004 r. o ochronie przyrody, tekst jednolity: Dz. U. z 2020 r. poz. 55 (dalej: u.o.p.).

13 Rozporządzenie Ministra Środowiska z dnia 20 grudnia 2004 r. w sprawie warunków hodowli i utrzymywania poszczególnych grup gatunków zwierząt w ogrodzie zoologicznym, Dz. U. z 2005 r. Nr 5, poz. 32 (dalej: rozporządzenie).

14 Ustalając znaczenie terminu: „zwierzęta gatunków dziko występujących” należy posiłkować się definicją pojęcia: „zwierzęta wolno żyjące (dzikie)”. Zgodnie z przepisem art. 4 pkt 21 u.o.z. są to zwierzęta nieudomowione, żyjące $w$ warunkach niezależnych od człowieka. W związku z powyższym zwierzętami gatunków dziko występujących będą przedstawiciele tych gatunków, które w warunkach naturalnych nie zostały udomowione przez człowieka, a ich egzystencja nie jest uzależniona od jego oddziaływanie na nie. 
więcej niż 15 gatunków tych zwierząt i łącznie nie więcej niż 50 okazów gadów, ptaków i ssaków. Katalog zwierząt, które mogą zostać umieszczone w ogrodach zoologicznych można ustalić zasadniczo na podstawie przepisów rozporządzenia - nie jest to jednak katalog wyczerpujący, z uwagi na umieszczone w nim pewne ogólne kategorie zwierząt (np. ryby morskie).

Biorąc pod uwagę dobro zwierząt utrzymywanych w ogrodach zoologicznych, ustawodawca wprowadza istotne ograniczenia co do cech tych zwierząt. Niedopuszczalna jest bowiem dowolność w tym zakresie. Wiąże się to przede wszystkim z koniecznością zagwarantowania ich ochrony humanitarnej i gatunkowej, a w pewnym zakresie również weterynaryjnej. W ogrodach zoologicznych mogą być utrzymywane wyłącznie zwierzęta wpisujące się $w$ minimum jedną $\mathrm{z}$ trzech kategorii. Zgodnie $\mathrm{z}$ brzmieniem art. 71 u.o.p. w ogrodach zoologicznych hoduje się i utrzymuje się zwierzęta, które: 1) urodziły się i wychowały poza środowiskiem przyrodniczym; 2) które poza ogrodem zoologicznym nie mają szansy przeżycia; 3) jeżeli wymaga tego ochrona populacji lub gatunku albo realizacja celów naukowych. Wydaje się, że pierwszeństwo w zakresie utrzymywania zwierząt określonych gatunków w ogrodach zoologicznych mają zwierzęta, które nie urodziły się i nie wychowały w swoim naturalnym środowisku. Ma to przede wszystkim na celu wyeliminowanie lub ograniczenie negatywnych odczuć zwierząt dzikich, które zostały pozbawione wolności w wyniku interwencji człowieka. Umieszczanie w ogrodach zoologicznych takich zwierząt powinno mieć miejsce wyjątkowo - tylko wówczas, gdy dotyczy to osobników, które, z obiektywnych powodów, nie mają szans na przeżycie w swoim środowisku naturalnym. Podkreślić należy jednocześnie, że nie dotyczy to wszystkich przedstawicieli gatunków zagrożonych wyginięciem, ale konkretnego osobnika, który znalazł się w warunkach grożących jego życiu (np. w związku z pewnym jego upośledzeniem lub pozbawieniem ochrony ze strony starszych osobników). Drugi przypadek wyjątkowego umieszczenia zwierząt dzikich w ogrodach zoologicznych dotyczy natomiast właśnie ochrony populacji lub gatunku albo realizacji celów naukowych. W doktrynie przyjmuje się, że wynika to z faktu, iż ogród zoologiczny jest jedynym miejscem, które może zapewnić istnienie konkretnego gatunku bądź są one niezbędne do przeprowadzenia badań naukowych, które służą realizacji powyższego 
zadania ${ }^{15}$. W kontekście tym, istotne jest, że poprzez hodowlę i utrzymywanie tych zwierząt $w$ ogrodach zoologicznych, realizowane są założenia ochrony gatunkowej zwierząt, wiążące się z dążeniem do przeciwdziałania wyginięciu poszczególnych gatunków zwierząt ${ }^{16}$ i zachowania równowagi w przyrodzie. Umieszczenie ich przedstawicieli w ogrodach zoologicznych ma bowiem na celu przywrócenie osobników tych gatunków do środowiska przyrodniczego (art. 47 ust. 2 u.o.p., art. 69 ust. 1 pkt 3 u.o.p.) ${ }^{17}$. Co więcej, ochrona gatunkowa zwierząt nie jest w żaden sposób różnicowana ze względu na typ, do którego zalicza się zgodnie z systematyką dany gatunek - obejmuje ona wszystkich przedstawicieli królestwa zwierząt. Może to prowadzić do pewnego dysonansu w zestawieniu z ochroną humanitarną zwierząt, która dotyczy wyłącznie zwierząt kręgowych.

\section{Regulacje prawne dotyczące humanitarnej ochrony zwierząt utrzymywanych w ogrodach zoologicznych}

Ustawa o ochronie zwierząt zawiera szereg przepisów prawnych odnoszących się do humanitarnego traktowania zwierząt. Weryfikując normy prawne dotyczące humanitarnej ochrony zwierząt utrzymywanych w ogrodach zoologicznych, należy oceniać je jednak w kontekście odpowiednich przepisów ustawy o ochronie przyrody oraz aktów wykonawczych do nich. Warto również zaznaczyć, że powyższa ochrona będzie normowana na gruncie dwóch głównych gałęzi prawa: administracyjnego oraz karnego. Odnosząc się do oceny niehumanitarnego traktowania zwierząt utrzymywanych w ogrodach zoologicznych, warto jednocześnie zaznaczyć, że z uwagi na subsydiarny charakter norm prawnokarnych,

15 Zob. K. Gruszecki, Ustawa o ochronie przyrody. Komentarz, Warszawa 2010, s. 314; T. Kaleta, Znaczenie i rodzaje badań naukowych prowadzonych na ssakach w ogrodach zoologicznych, "Zeszyty Naukowe. Przegląd Hodowlany" 2002, t. 60, s. 165 i nast.

16 Zob. S. Kasprzak, Normatywny wymiar ekologicznych $i$ sozologicznych idei w systemie prawa państwowego i kościelnego, Lublin 2003, s. 390.

17 Zob. W. Olech, Ochrona zasobów genowych zwierząt realizowana w ogrodach zoologicznych, „Przegląd Hodowlany” 2003, nr 9, s. 10 i nast.; A.G. Kruszewicz, Rola ogrodów zoologicznych w ratowaniu ginacych gatunków i poprawianiu dobrostanu zwierząt nieudomowionych, „Przegląd Hodowlany” 2011, nr 11, s. 8 i nast.; tenże, Ogrody zoologiczne a zachowanie gatunków, „Przyroda Polska” 2009, nr 2, s. 34 i nast. 
znajdują one zastosowanie dopiero wówczas, gdy sankcje administracyjne okażą się niewystraczające lub nie będzie możliwości chronienia dobra zwierząt $\mathrm{w}$ inny sposób ${ }^{18}$.

Ustawa o ochronie przyrody zawiera szereg wymogów związanych z utworzeniem i prowadzeniem ogrodu zoologicznego. Warunki te wskazane zostały w art. 67 u.o.p. Zgodnie z art. 68 ust. 1 u.o.p. Generalny Dyrektor Środowiska może cofnąć lub zmienić zezwolenie, na utworzenie i prowadzenie ogrodu zoologicznego, jeżeli podmiot, który je uzyskał: nie spełnia warunków prowadzenia działalności ogrodu zoologicznego; nie przestrzega zakresu działalności ogrodu zoologicznego; nie spełnia obowiązków, o których mowa w art. 69 ust. 1 u.o.p. (uczestniczenie w badaniach naukowych, które mają na celu ochronę gatunków zagrożonych wyginięciem w stanie wolnym; edukacja w zakresie ochrony gatunkowej zwierząt, z uwzględnieniem różnorodności biologicznej; prowadzenie hodowli zwierząt gatunków zagrożonych wyginięciem, w celu ich ochrony ex situ, a następnie wprowadzenie do środowiska przyrodniczego $\mathrm{w}$ ramach ochrony tych gatunków; przetrzymywanie zwierząt $w$ warunkach odpowiadających ich potrzebom biologicznym; prowadzenie dokumentacji hodowlanej ${ }^{19}$ ); nie spełnia warunków określonych w przepisach, o których mowa $w$ art. 70 u.o.p. (dotyczy to przepisów rozporządzenia Ministra Środowiska z dnia 20 grudnia 2004 r. w sprawie warunków hodowli i utrzymywania poszczególnych grup gatunków zwierząt w ogrodzie zoologicznym). Jeżeli powyższe pozwolenie na utworzenie i prowadzenie ogrodu zoologicznego zostanie cofnięte, ogród zoologiczny podlega likwidacji (art. 68 ust. 2 u.o.p.). W decyzji o cofnięciu zezwolenia podaje się termin jej wykonania oraz wskazuje organ nadzorujący likwidację ogrodu zoologicznego (art. 68 ust. 4 u.o.p. $)^{20}$.

Niehumanitarne traktowanie zwierząt - związane np. z przetrzymywaniem ich $\mathrm{w}$ warunkach, które nie odpowiadają ich potrzebom biologicznym - może skutkować zatem cofnięciem pozwolenia na prowadzenie ogrodu zoologicznego, ponieważ nie spełnia on wówczas celu, dla którego został utworzony. Wszelkie potencjalne nieprawidłowości

18 Zob. A. Grześkowiak, K. Wiak (red.), Prawo karne, Warszawa 2017, s. 8.

19 Zob. A. Niweliński, Rola i funkcje współczesnych ogrodów zoologicznych, „Przyroda Polska" 2001, nr 11, s. 10 i nast.

20 Zob. A. Ronikier-Dolańska, Przepisy prawa krajowego w zakresie funkcjonowania ogrodów zoologicznych, [w:] T. Gardocka i in. (red.), Dobrostan zwierząt w ogrodach zoologicznych a standardy prawne UE, Warszawa 2014, s. 86 i nast. 
w tym zakresie mogą zostać stwierdzone podczas kontroli przeprowadzanej przez regionalnego dyrektora ochrony środowiska właściwego ze względu na miejsce położenia ogrodu zoologicznego (art. 77 ust. 1 u.o.p.). Taka kontrola jest przeprowadzana nie rzadziej niż raz na 3 lata i dokonywana jest $\mathrm{z}$ własnej inicjatywy regionalnego dyrektora ochrony środowiska lub na wniosek Generalnego Dyrektora Ochrony Środowiska (art. 77 ust. 2 u.o.p.). Osoba przeprowadzająca czynności kontrolne, sporządza z nich protokół (art. 77 ust. 7 u.o.p.). ${ }^{21}$.

Odnośnie do odpowiedzialności karnej za niehumanitarne traktowanie zwierząt utrzymywanych w ogrodach zoologicznych zasadniczą rolę odgrywają art. 6 ust. 1a oraz art. 35 u.o.z. Pierwszy z nich zawiera zakaz znęcania się nad zwierzętami, natomiast drugi stanowi podstawę kryminalizacji znęcania się nad zwierzętami. Powyższe zachowanie jest zagrożone na gruncie przepisu art. 35 ust. 1a u.o.z. karą pozbawienia wolności do lat 3. Dodatkowo ustawodawca przewidział surowszą karę za znęcanie się nad zwierzętami ze szczególnym okrucieństwem - od 3 miesięcy do lat 5 (art. 35 ust. 2 u.o.z.). Co więcej, w przypadku dopuszczenia się przestępstwa znęcania się nad zwierzętami, ustawodawca przewidział możliwość orzeczenia: odpowiedniego środka penalnego (obligatoryjnie lub fakultatywnie) - zakazu posiadania wszelkich zwierząt albo określonej kategorii zwierząt; zakazu wykonywania wszelkich lub określonych zawodów, prowadzenia wszelkiej lub określonej działalności lub wykonywania wszelkich lub określonych czynności wymagających zezwolenia - który jest związany z wykorzystywaniem zwierząt lub oddziaływaniem na nie; przepadku przedmiotów, które służyły lub były przeznaczone do popełnienia przestępstw; nawiązki na wskazany cel związany z ochroną zwierząt ${ }^{22}$.

Ocena czym jest zachowanie polegające na znęcaniu się nad zwierzętami jest problemem złożonym. Zgodnie z przepisem art. 6 ust. 2 u.o.z. przez znęcanie się nad zwierzętami należy rozumieć zadawanie albo świadome dopuszczanie do zadawania bólu lub cierpień. W obszernym katalogu zawartym w tym przepisie ustawodawca wskazał przykładowe - często bardzo kazuistyczne - zachowania zakwalifikowane jako znęcanie

${ }^{21}$ Zob. W. Radecki, Kontrola w ochronie przyrody, „Przyroda Polska” 2008, nr 1, s. 10; A. Ronikier-Dolańska, Przepisy prawa krajowego..., s. 90 i nast.

22 Szerzej zob. Z. Gądzik, Środki karne, przepadek zwierzęcia i nawiąka w ustawie z dnia 21 sierpnia 1997 r. o ochronie zwierzat, „Prokuratura i Prawo” 2019, nr 3, s. 75 i nast. 
się nad zwierzętami²3. Zaznaczyć należy jednak, że powyższy katalog ma charakter otwarty i nie obejmuje wszystkich przestępnych zachowań związanych ze znęcaniem się nad zwierzętami - mogą być nimi zarówno modyfikacje przedstawionych w nim przypadków, jak i całkiem inne zachowania związane z zadawaniem zwierzętom bólu lub cierpienia. Warto jednak zwrócić uwagę, iż niektóre z przedstawionych w nim przykładów mogą odnosić się $\mathrm{w}$ określonych przypadkach do zwierząt utrzymywanych w ogrodach zoologicznych. Co istotne, przyjmuje się, że przestępstwo znęcania się nad zwierzętami jest przestępstwem formalnym. Oznacza to, że do jego popełnienia nie jest konieczne wystąpienie określonych skutków (np. w postaci naruszenia integralności cielesnej zwierzęcia lub spowodowania jego rozstroju zdrowia). Uznać należy, że wystarczające jest podjęcie zachowań, które są nastawione na zadawanie zwierzętom bólu lub cierpienia ${ }^{24}$.

Zgodnie z orzecznictwem Sądu Najwyższego (SN) przestępstwa znęcania się nad zwierzętami można dopuścić się wyłącznie umyślnie - tylko z zamiarem bezpośrednim ${ }^{25}$. Istotne jest również, że zamiar odnosi się do samej czynności sprawczej, a nie tylko do spowodowania bólu lub cierpienia. Co więcej, za przestępstwo z art. 35 ust. 1a u.o.z. odpowie nie tylko osoba, która zadaje zwierzęciu bezpośrednio ból lub cierpienie, ale również ten, kto w sposób świadomy dopuszcza do zadawania zwierzęciu bólu lub cierpienia przez inną osobę. Przez dopuszczanie rozumieć należy nie przeciwdziałanie, czyli przyzwolenie na określone zachowania. Jest ono świadome, gdy sprawca zdaje sobie sprawę z następstw swojego

23 Zob. M. Szwejkowska, W. Truszkowski, Przestępstwa znęcania się nad zwierzetami w świetle ustawy z 21 sierpnia 1997 r. o ochronie zwierząt, [w:] W. Pływaczewski, A. Nowak, M. Porwisz (red.), Przeciwdziałanie międzynarodowej przestępczości przeciwko środowisku naturalnemu z perspektywy organów ściagania, Szczytno 2017, s. 96 i nast.; M. Mozgawa, [w:] M. Mozgawa (red.), Pozakodeksowe przestępstwa przeciwko zasobom przyrody i środowisku. Komentarz, Warszawa 2017, s. 75 i nast.

24 Zob. Z. Gądzik, Prawnokarna ocena stosowania dopingu u zwierząt, „Prokuratura i Prawo" 2017, nr 7/8, s. 69; M. Mozgawa i in., Prawnokarna ochrona zwierząt - analiza dogmatyczna i praktyka ścigania przestęstw z art. 35 ustawy z 21.08.1997 r. o ochronie zwierzat, "Prawo w Działaniu" 2011, nr 9, s. 48.

25 Zob. wyrok SN z dnia 13 grudnia 2016 r., II KK 281/16, LEX nr 2237277; wyrok SN z dnia 16 listopada 2009 r., V KK 187/09, LEX nr 553896; odmiennie M. Gabriel-Węglowski, Glosa do wyroku SN z dnia 16 listopada 2009 r., V KK 187/09, LEX/el. 2010. 
zachowania związanego z przyzwoleniem innej osobie na zachowania stanowiące przejaw znęcania się nad zwierzętami ${ }^{26}$.

Zgodnie z przepisem art. 6 ust. 2 pkt 10 u.o.z. znęcaniem się nad zwierzętami będzie utrzymywanie zwierząt $\mathrm{w}$ niewłaściwych warunkach bytowania, $\mathrm{w}$ tym utrzymywanie ich $\mathrm{w}$ stanie rażącego zaniedbania lub niechlujstwa bądź w pomieszczeniach albo klatkach uniemożliwiających im zachowanie naturalnej pozycji. Zwierzęta utrzymywane $w$ ogrodach zoologicznych to niejednokrotnie przedstawiciele gatunków zwierząt, które nie stanowią rodzimej fauny państwa, w którym mieści się ogród zoologicznych. Często są to gatunki, które w środowisku naturalnym występują w skrajnie odmiennych strefach klimatycznych. Pomimo że większość osobników przebywających w ogrodach zoologicznych urodziła się lub wychowała poza swoim naturalnym środowiskiem, co w pewnym zakresie zwiększa stopień przystosowania do odmiennych warunków bytowych, nie należy zapominać, że $\mathrm{w}$ dalszym ciągu są to przedstawiciele gatunków ewolucyjnie przystosowanych do życia w określonym klimacie i w określonych miejscach. Wiąże się to z koniecznością dostosowania miejsc przeznaczonych do przetrzymywania tych zwierząt do ich naturalnych potrzeb. Wymóg taki wynika z przepisu art. 72 ust. 1 u.o.p., zgodnie z którym do ogrodów zoologicznych sprowadza się tylko te zwierzęta, którym w ogrodzie można zapewnić warunki odpowiadające potrzebom biologicznym danego gatunku. Wskazane powyżej rozporządzenie Ministra Środowiska określa warunki hodowli i utrzymywania poszczególnych grup zwierząt, $\mathrm{w}$ tym: niezbędne pomieszczenia i wyposażenie $\mathrm{w}$ urządzenia techniczne miejsc przebywania zwierząt poszczególnych gatunków lub grup gatunków; minimalne warunki przestrzenne dla hodowli i utrzymywania zwierząt poszczególnych gatunków lub grup gatunków; niezbędne warunki do prowadzenia reprodukcji zwierząt poszczególnych gatunków lub grup gatunków (§ 1 rozporządzenia). Zgodnie z przepisem $\S 3$ rozporządzenia pomieszczenia do przetrzymywania zwierząt należy, w zależności od typu pomieszczenia, wyposażyć odpowiednio w urządzenia umożliwiające: wietrzenie, dostosowanie temperatury, wilgotności i oświetlenia do wymogów poszczególnych gatunków, a w indywidualnych przypadkach do potrzeb zwierząt, z uwzględnieniem ciężarnych samic oraz noworodków, ukrycie się zwierząt, utrzymywanie czystości, odprowadzanie nadmiaru wody, regularne usuwanie zużytej

26 Wyrok SN z dnia 16 listopada 2009 r., V KK 187/09, LEX nr 553896. 
podściółki, regularną kontrolę jakości wody w akwariach i basenach, opiekę weterynaryjną, podawanie wody i karmy. Minimalne warunki przestrzenne dla hodowli i utrzymywania zwierząt poszczególnych gatunków lub grup gatunków są określone w załączniku do rozporządzenia (§ 4 rozporządzenia) $)^{27}$.

Przepisy rozporządzenia wprowadzają pewnego rodzaju fikcję, mającą na celu zapewnić zwierzętom utrzymywanym w ogrodach zoologicznych warunki zbliżone do ich środowiska naturalnego. Minimalne wymogi, uregulowane prawnie nie są w stanie zastąpić jednak realiów, w których żyją zwierzęta poszczególnych gatunków na wolności. Ich przestrzeganie ma natomiast zagwarantować utrzymywanie zwierząt $\mathrm{w}$ warunkach, w których zwierzęta te nie będą odczuwać bólu lub cierpienia w związku ze zbyt małą powierzchnią, w której nie mogłyby zachować naturalnej pozycji (np. pomieszczeń zbyt niskich) lub odczuwać innego rodzaju dyskomfort (np. w sytuacji zbyt dużej liczby osobników umieszczonych $\mathrm{w}$ jednym pomieszczeniu). Przewidziane $\mathrm{w}$ rozporządzeniu wymogi mają w założeniu zapewnić nie tylko odpowiednią przestrzeń życiową, ale również mają czynić zadość naturalnym potrzebom i zachowaniom typowym dla danego gatunku (wspinanie się, pływanie, odpowiednia ilość ruchu itp. $)^{28}$. Brak zagwarantowania zwierzętom utrzymywanym w ogrodach zoologicznych tych minimalnych wymogów, może zostać zakwalifikowane

27 Załącznik do rozporządzenia zawiera dane odnoszące się (w zależności od gromady zwierząt) do powierzchni pomieszczeń zewnętrznych i wewnętrznych (w zależności od ilości osobników), innego niezbędnego wyposażenia, wielkości terrarium, poziomu wody $\mathrm{w}$ basenie, temperatury pod źródłem ciepła, uwarunkowań socjalnych, wilgotności powietrza, wymagań dotyczących dostępu do świeżego powietrza itd.

28 Przykładowo, dla większości zwierząt z gatunków kotowatych (np. tygrysa, pumy, pantery śnieżnej) wymagane są urządzenia do wspinania się; dla dzików konieczne jest zapewnienie podłoża umożliwiającego kopanie; dla gatunków małp z rodzaju pawiany wymagane jest zapewnienie urządzeń do wspinania się i przebywania ponad powierzchnią podłoża. Ponadto zob. K. Pullen, Dobrostan naczelnych w ogrodach zoologicznych, [w:] T. Gardocka i in. (red.), Dobrostan zwierząt w ogrodach zoologicznych a standardy prawne UE, Warszawa 2014, s. 128; R. Maślak i in., The Welfare of Bears in Zoos. A Case Study of Poland, "Journal of Applied Animal Welfare Science” 2016, t. 19, s. 24 i nast.; A. Demartoto, R.B. Soemanto, S. Zunariyah, Zoo Agent's Measure in Applying the Five Freedoms Principles for Animal Welfere, „Weterinary World” 2017, t. 10, s. 1026 i nast.; K.H. Hassan, Occupational and Animals Safety in zoos. A legal narrative, "American Journal of Animal and Veterinary Sciences" 2013, t. 9, s. 1 i nast. 
jako przejaw znęcania się nad nimi ${ }^{29}$ - może bowiem wiązać się z odczuwaniem przez nie cierpienia wynikającego z braku możliwości realizacji ich naturalnych, biologicznych potrzeb, a także skutkować pogorszeniem ich stanu fizycznego (np. w postaci zaburzenia narządów ruchu, stanów zapalnych, zwyrodnień kończyn, samookaleczeń itp.) ${ }^{30}$. Analogicznie ocenić należy również brak wymaganego wyposażenia, umożliwiającego zwierzętom ukrycie się (zwłaszcza uwzględniając zachowanie niektórych osób wizytujących ogrody zoologiczne), jak również możliwość oddzielenia od siebie poszczególnych osobników (w związku z ryzykiem ich wzajemnych ataków).

Przejawem znęcania się nad zwierzętami utrzymywanymi w ogrodach zoologicznych, w powyższym kontekście zagwarantowania im odpowiednich warunków bytowania, jest utrzymywanie ich w stanie rażącego zaniedbania lub niechlujstwa. Może się to wiązać przede wszystkim z brakiem zapewnienia stosownego zaplecza, o którym mowa w przepisie $\S 3$ rozporządzenia, dzięki któremu możliwe będzie utrzymywanie czystości w pomieszczeniu, którym przebywają zwierzęta, odprowadzanie z nich nadmiaru wody, regularne usuwanie zużytej podściółki oraz regularna kontrola jakości wody w akwariach i basenach. Kolejnym przejawem realizacji znamion przestępstwa znęcania się nad zwierzętami będą wszelkiego rodzaju zaniedbania ze strony osób odpowiedzialnych za utrzymywanie porządku w pomieszczeniach, w których przebywają zwierzęta, w stopniu, który będzie można uznać za rażący. Przyjmuje się, że zwrot "rażące niechlujstwo" rozumieć należy jako część pojęcia „rażące zaniedbanie" (art. 4 pkt 11 u.o.z.), a więc drastyczne odstępstwo od określonych w ustawie norm postępowania ze zwierzęciem, a w szczególności w zakresie utrzymywania zwierzęcia w stanie zagłodzenia, brudu, nie leczonej choroby, w niewłaściwym pomieszczeniu i nadmiernej ciasnocie. Rażącym niechlujstwem będzie zatem drastyczne odstępstwo

29 Pogląd ten znajduje również potwierdzenie w orzecznictwie. Zgodnie z wyrokiem Wojewódzkiego Sądu Administracyjnego w Warszawie z dnia 20 października 2017 r., IV SA/Wa 55/17, LEX nr 2480338: „Znęcanie się nad zwierzęciem to nie tylko fizyczne zadawanie mu bólu, to również przetrzymywanie go w takich warunkach, które nie spełniają jego podstawowych potrzeb, jak również długotrwałe niewłaściwe opiekowanie się nim, prowadzące do uszczerbku na jego zdrowiu zarówno fizycznym jak i psychicznym".

30 Zob. A. Sergiel, R. Maślak, Dobrostan niedźwiedzi w niewoli, [w:] T. Gardocka i in. (red.), Dobrostan zwierząt w ogrodach zoologicznych a standardy prawne UE, Warszawa 2014, s. 142. 
od należytego traktowania i utrzymywania zwierzęcia $\mathrm{w}$ zakresie jego czystości i higieny $^{31}$. Podstawowe wymogi związane z zapewnieniem odpowiedniego poziomu czystości w pomieszczeniach, w których utrzymywane są zwierzęta, określa rozporządzenie Ministra Środowiska z dnia 10 grudnia 2003 r. w sprawie bezpieczeństwa i higieny pracy w ogrodach zoologicznych ${ }^{32}$. Zgodnie z $\S 4$ powyższego rozporządzenia, w pomieszczeniach do utrzymywania zwierząt m.in.: utrzymuje się czystość i porządek, w tym regularnie usuwa odchody i resztki pokarmu oraz przeprowadza regularną dezynfekcję, dezynsekcję i deratyzację; utrzymuje się w sprawności urządzenia wentylacyjne; nie dopuszcza się do zagrzybienia ścian i sufitów.

Zgodnie z art. 6 ust. 2 pkt 17 u.o.z., znęcaniem się nad zwierzętami będzie wystawianie zwierzęcia domowego lub gospodarskiego na działanie warunków atmosferycznych, które zagrażają jego zdrowiu lub życiu. Powyższy przejaw znęcania się nad zwierzętami można odnieść również do zwierząt utrzymywanych w ogrodach zoologicznych. Pomimo że nie są one zwierzętami domowymi lub gospodarskimi, otwarty charakter katalogu zawartego $\mathrm{w}$ przepisie art. 6 ust. 2 u.o.z., pozwala na traktowanie wszelkiego rodzaju zachowań związanych z narażaniem zwierząt na niekorzystne działanie warunków atmosferycznych za przejaw znęcania się nad nimi. Będzie to dotyczyło wszystkich sytuacji, w których zwierzę utrzymywane $w$ ogrodzie zoologicznym przebywa $w$ warunkach niedostosowanych do jego naturalnych potrzeb (związanych $\mathrm{z}$ temperaturą wody i powietrza, wilgotnością powietrza, wymaganiami dotyczącymi dostępu do świeżego powietrza itd.), w sposób, który może narazić zwierzę na ból lub cierpienie, a nawet doprowadzić do rozstroju jego zdrowia lub śmierci zwierzęcia. Podkreślić bowiem należy, że znakomita część zwierząt przebywających w ogrodach zoologicznych, to zwierzęta żyjące $w$ innych strefach klimatycznych - a co za tym idzie - wymagających stworzenia dla nich sztucznych warunków, umożliwiających ich bytowanie $^{33}$. W związku z tym, za przejaw znęcania się nad zwierzętami uznać należy np. przetrzymywanie zwierząt strefy równikowej na mrozie lub

31 Zob. M. Gabriel-Węglowski, Przestępstwa przeciwko humanitarnej..., s. 100.

32 Rozporządzenie Ministra Środowiska z dnia 10 grudnia 2003 r. w sprawie bezpieczeństwa i higieny pracy w ogrodach zoologicznych, Dz. U. z 2004 r. Nr 4, poz. 26.

33 Zob. T. Kaleta, Wzbogacenie środowiskowe a dobrostan zwierząt dzikich w ogrodach zoologicznych, „Przegląd Hodowlany” 2014, nr 3, s. 20 i nast. 
uniemożliwienie zwierzętom polarnym odpowiedniego ochłodzenia się podczas upałów. Przekłada się to bezpośrednio na zagwarantowanie odpowiedniego zaplecza technicznego, umożliwiającego hodowlę i utrzymywanie zwierząt w ogrodach zoologicznych w sposób dostosowany do cyklu dobowego i rocznego.

Problematyczna wydaje się kwestia umieszczania w ogrodach zoologicznych zwierząt, które urodziły się i wychowały na wolności. Zwierzę takie jest zasadniczo nieprzystosowane do życia w niewoli, a konieczność adaptacji wiąże się z jego silnym stresem i cierpieniem. W związku z powyższym umieszczenie takiego osobnika w ogrodzie zoologicznym powinno być traktowane jako forma znęcania się nad nim. Ustawodawca poczynił jednak wyłączenia w tym zakresie. Nie będzie czynem bezprawnym umieszczenie w ogrodzie zoologicznym zwierząt, które urodziły się i wychowały na wolności, jeżeli poza ogrodem zoologicznym nie mają szansy przeżycia lub jeżeli wymaga tego ochrona populacji lub gatunku albo realizacja celów naukowych. Przyjąć bowiem należy, że zachowanie takie jest nakierowane na uzyskanie wartości wyższych niż wolność zwierzęcia od cierpienia.

Wśród innych przejawów znęcania się nad zwierzętami, ustawodawca wymienia również złośliwe drażnienie lub straszenie zwierząt (art. 6 ust. 2 pkt 9 u.o.z.). Pomimo że regulaminy porządkowe ogrodów zoologicznych zawierają szereg zakazów ${ }^{34}$ związanych z przeciwdziałaniem powyższym zdarzeniom, zaobserwować można zachowania niektórych odwiedzających, które mogą wiązać się z wywołaniem u zwierząt poczucia strachu lub zagrożenia ${ }^{35}$. W ich wyniku zwierzęta mogą popaść w stan zwierzęcej depresji, wiążący się m.in. z utratą apetytu, bezsennością, zaprzestaniem rozmnażania oraz otępieniem ${ }^{36}$. Zachowania te mogą polegać na niepokojeniu zwierząt (np. poprzez intensywne stukanie w szybę, krzyk), rzucaniu w nie przedmiotami, używanie w ich bliskiej obecności

34 Zob. Regulamin zwiedzania Miejskiego Ogrodu Zoologicznego w Warszawie, https:/ / zoo.waw.pl/wizyta-w-zoo/przed-wizyta-w-zoo-przeczytaj [dostęp: 3.02.2020 r.].

${ }_{35}$ Zob. T. Kaleta, Zachowanie sie zwierząt w ogrodach zoologicznych a ich dobrostan, [w:] T. Gardocka i in. (red.), Dobrostan zwierząt w ogrodach zoologicznych a standardy prawne UE, Warszawa 2014, s. 121 i nast.

${ }^{36}$ Zob. H. Dyga, Smutek za kratami, czyi prawda o cierpieniu zwierząt w cyrkach $i$ zoo, „Zielone Brygady. Pismo Ekologów” 2007, nr 3, s. 27; Ł. Smaga, Ochrona humanitarna..., s. 262; D.G. Kleiman, K.V. Thomson, Ch.K. Baer, Wild Mammals in Captivity. Principles $\mathcal{E}$ Techniques for Zoo Management, Chicago-London 2010. 
dronów, hałaśliwych urządzeń, artykułów pirotechnicznych (np. petard) itp. Jeżeli powyższemu zachowaniu sprawcy przypisać można zamiar wywołania u zwierzęcia poczucia strachu, a co za tym idzie - pewnej formy cierpienia, wypełnia on znamiona przestępstwa znęcania się nad zwierzętami.

\section{Zakończenie}

Przedstawiona problematyka ochrony humanitarnej zwierząt utrzymywanych w ogrodach zoologicznych, wskazuje, że nie stanowi ona problemu abstrakcyjnego. Specyfika hodowli tego typu zwierząt wiąże się z koniecznością spełniania wymagających warunków, które z jednej strony mają zagwarantować realizację przez ogrody zoologiczne przypisanych im funkcji, a z drugiej - zapewnić odpowiednie traktowanie zwierząt i ich ochronę przed zadawaniem im bólu lub cierpienia. Kwestia ta wydaje się szczególnie istotna biorąc pod uwagę częsty brak naturalnego przystosowania zwierząt do warunków środowiskowych panujących w danym kraju.

Pomimo tego, że wydaje się, iż w przypadku ogrodów zoologicznych zasadniczą rolę odgrywa przede wszystkim konieczność zapewnienia ochrony gatunkowej zwierząt, nie należy zapominać, że wszystkie prawne aspekty ochrony zwierząt (ochrona humanitarna, gatunkowa, użytkowa i weterynaryjna) wzajemnie się uzupełniają i przenikają. $Z$ tego powodu nie jest możliwe zapewnienie ochrony gatunków zwierząt utrzymywanych w ogrodach zoologicznych, bez zapewnienia ich humanitarnego traktowania. Niewłaściwe traktowanie zwierząt utrzymywanych w ogrodach zoologicznych może przekładać się automatycznie na utrudnienia w ochronie ex situ gatunków zagrożonych wyginięciem, a tym samym zaprzepaszczać cel, dla którego ogrody zoologiczne zostały ustanowione.

Ustawodawca wprowadził surowe sankcje za naruszenia przepisów związanych z humanitarnym traktowaniem zwierząt utrzymywanych w ogrodach zoologicznych. Wiążą się one nie tylko z likwidacją ogrodu zoologicznego, ale również z surowymi sankcjami karnymi, także utratą prawa do wykonywania dotychczasowego zawodu. W tym względzie wydaje się zatem, że przepisy - zarówno administracyjne, jak i karne spełniają swoją rolę prewencyjną i odstraszają od potencjalnych nadużyć. Wydaje się natomiast, że pewnego rodzaju dopracowania wymagają 
przepisy odnoszące się do kontroli przestrzegania przepisów związanych z utrzymywaniem i hodowlą zwierząt $\mathrm{w}$ ogrodach zoologicznych. Biorąc pod uwagę szczególne warunki, w których przebywają te zwierzęta, słuszne byłoby wprowadzenie pewnych zmian dotyczących częstotliwości i zakresu dokonywanej kontroli - ze szczególnym naciskiem na ochronę humanitarną zwierząt.

Zasadne byłoby również zmodyfikowanie uregulowań w zakresie ochrony zwierząt bezkręgowych. Pomimo tego, że de facto nie podlegają one ochronie na gruncie ustawy z dnia 21 sierpnia 1997 r. o ochronie zwierząt, a warunki ich utrzymywania zostały sformułowane bardzo ogólnie, uwzględniając specyfikę i cel ich utrzymywania w ogrodach zoologicznych, wprowadzone powinny zostać odpowiednie sankcje za niewłaściwe oddziaływanie na nie.

Słowa kluczowe: ogród zoologiczny, ochrona humanitarna zwierząt, znęcanie się nad zwierzętami, prawna ochrona zwierząt

\section{Bibliografia}

Demartoto A., R.B. Soemanto, S. Zunariyah, Zoo Agent's Measure in Applying the Five Freedoms Principles for Animal Welfare, „Weterinary World” 2017, t. 10.

Dyga H., Smutek za kratami, czyli prawda o cierpieniu zwierzat w cyrkach i zoo, „Zielone Brygady. Pismo Ekologów" 2007, nr 3.

Gabriel-Węglowski M., Glosa do wyroku SN z dnia 16 listopada 2009 r., V KK 187/09, LEX/el. 2010.

Gabriel-Węglowski M., Przestępstwa przeciwko humanitarnej ochronie zwierząt, Torun 2008.

Gądzik Z., Prawnokarna ocena stosowania dopingu u zwierzat, „Prokuratura i Prawo" 2017, nr 7/8.

Gądzik Z., Prawnokarna ochrona zwierząt wykorzystywanych w procedurach doświadczalnych, Lublin 2018.

Gądzik Z., Środki karne, przepadek zwierzęcia i nawiazka w ustawie $z$ dnia 21 sierpnia 1997 r. o ochronie zwierząt, „Prokuratura i Prawo” 2019, nr 3.

Gruszecki K., Ustawa o ochronie przyrody. Komentarz, Warszawa 2010.

Grześkowiak A., K. Wiak (red.), Prawo karne, Warszawa 2017.

Hassan K.H., Occupational and Animals Safety in Zoos. A Legal Narrative, "American Journal of Animal and Veterinary Sciences" 2013, t. 9. 
Jastrzębski L., Prawo ochrony środowiska w Polsce, Warszawa 1990.

Kaleta T., Wzbogacenie środowiskowe a dobrostan zwierząt dzikich w ogrodach zoologicznych, "Przegląd Hodowlany” 2014, nr 3.

Kaleta T., Zachowanie się zwierząt wo ogrodach zoologicznych a ich dobrostan, [w:] T. Gardocka $\mathrm{i}$ in. (red.), Dobrostan zwierząt w ogrodach zoologicznych a standardy prawne UE, Warszawa 2014.

Kaleta T., Znaczenie i rodzaje badań naukowych prowadzonych na ssakach w ogrodach zoologicznych, "Zeszyty Naukowe. Przegląd Hodowlany” 2002, t. 60.

Kasprzak S., Normatywny wymiar ekologicznych i sozologicznych idei w systemie prawa państwowego i kościelnego, Lublin 2003.

Kleiman D.G., K.V. Thomson, Ch.K. Baer, Wild Mammals in Captivity. Principles $\mathcal{E}$ Techniques for Zoo Management, Chicago-London 2010.

Kruszewicz A.G., Ogrody zoologiczne a zachowanie gatunków, „Przyroda Polska” 2009, nr 2.

Kruszewicz A.G., Rola ogrodów zoologicznych w ratowaniu ginacych gatunków i poprawianiu dobrostanu zwierząt nieudomowionych, "Przegląd Hodowlany" 2011, nr 11.

Majewski A., Aksjologiczne podstawy prawnej ochrony zwierząt w aspekcie humanitarnym, "Gdańskie Studia Prawnicze” 2000, t. 7.

Majewski A., Prawa człowieka a prawa zwierzat, "Gdańskie Studia Prawnicze" 2005, t. 13.

Maślak R. i in., The Welfare of Bears in Zoos. A Case Study of Poland, "Journal of Applied Animal Welfare Science" 2016, t. 19.

Mozgawa M. (red.), Pozakodeksowe przestępstwa przeciwko zasobom przyrody i środowisku. Komentarz, Warszawa 2017.

Mozgawa M. i in., Prawnokarna ochrona zwierząt - analiza dogmatyczna i praktyka ścigania przestepstw z art. 35 ustawy z 21.08.1997 r. o ochronie zwierzat, "Prawo w Działaniu" 2011, nr 9.

Niweliński A., Rola i funkcje współczesnych ogrodów zoologicznych, „Przyroda Polska" 2001, nr 11.

Olech W., Ochrona zasobów genowych zwierząt realizowana w ogrodach zoologicznych, „Przegląd Hodowlany” 2003, nr 9.

Pullen K., Dobrostan naczelnych w ogrodach zoologicznych, [w:] T. Gardocka i in. (red.), Dobrostan zwierzat w ogrodach zoologicznych a standardy prawne UE, Warszawa 2014.

Radecki W., Kontrola w ochronie przyrody, „Przyroda Polska” 2008, nr 1.

Radecki W., Ustawa o ochronie zwierzat. Komentarz, Warszawa 2012.

Ronikier-Dolańska A., Przepisy prawa krajowego w zakresie funkcjonowania ogrodów zoologicznych, [w:] T. Gardocka i in. (red.), Dobrostan zwierząt w ogrodach zoologicznych a standardy prawne UE, Warszawa 2014. 
Sergiel A., R. Maślak, Dobrostan niedźwiedzi w niewoli, [w:] T. Gardocka i in. (red.), Dobrostan zwierzat $w$ ogrodach zoologicznych a standardy prawne UE, Warszawa 2014.

Smaga Ł., Ochrona humanitarna zwierząt, Białystok 2010.

Szwejkowska M., W. Truszkowski, Przestępstwa znęcania się nad zwierzętami w świetle ustawy z 21 sierpnia 1997 r. o ochronie zwierząt, [w:] W. Pływaczewski, A. Nowak, M. Porwisz (red.), Przeciwdziałanie międzynarodowej przestępczości przeciwko środowisku naturalnemu z perspektywy organów ściagania, Szczytno 2017.

Woleński J., Podmiotowość zwierząt w aspekcie filozoficznym, [w:] T. Gardocka, A. Gruszczyńska (red.), Status zwierzęcia. Zagadnienia filozoficzne i prawne, Toruń 2012.

\section{HUMANITARIAN PROTECTION OF ANIMALS KEPT IN ZOOS}

\section{Sum mary}

The article concerns legal regulations related to a special category of animals which are animals kept in zoos - in the context of their humanitarian protection. It elaborates upon the issues related to the idea of humanitarian protection, issues related to its limitation to vertebrate animals only, as well as the conditions that zoos must meet to ensure the protection of animals living in them, the state of compliance with legal provisions related to the humanitarian protection of animals kept in zoos and consequences associated with their violation - both at the level of administrative and criminal law.

Key words: zoo, humanitarian protection of animals, animal abuse, legal protection of animals

\section{ГУМАНИТАРНАЯ ЗАЩИТА ЖИВОТНЫХ, СОДЕРЖАЩИХСЯ В ЗООПАРКАХ}

\section{Резюме}

В статье рассматриваются правовые нормы, относящиеся к особой категории животных, содержащихся в зоопарках, - в контексте их гуманитарной защиты. В рамках статьи затронуты, в частности, вопросы, связанные с идеей гуманитарной защиты, вопросы, связанные с ее ограниченностью до уровня только позвоночных животных, а также условиями, которым должны соответствовать зоопарки для обеспечения защиты животных, проживающих в них, состоянием соблюдения правовых положений, касающихся 
гуманитарной защиты животных, содержащихся в зоопарках, и последствиями нарушения таких положений - как в области административного, так и уголовного законодательства.

Ключевые слова: Зоопарк; гуманитарная защита животных; издевательство над животными; правовая защита животных 